\title{
Does Regulatory Jurisdiction Affect the Quality of Investment-Adviser Regulation? Online Appendix
}

\author{
Ben Charoenwong \\ Alan Kwan \\ Tarik Umar
}

\section{A Additional Results \& Robustness}

In this section, we present additional results consistent with a lowering of service quality, but that did not provide incremental identification power for the different plausible explanations of increased complaints. These results include (1) assortative matching of transitioned firms and transitioned advisers, and (2) RIAs that re-register with the SEC after transitioning from the SEC to state regulators due to the Dodd-Frank Act.

We also provide additional alternative specifications for various tests. We tackle the robustness of our results to (1) variation across states in the ease of filing complaints, (2) the choice of outcome variables and alternative samples, (3) different reporting requirements between SEC and state regulators, (4) spurious results due to cross-sectional or additional time-series correlations, (5) local economic and political conditions that may be suggestive of regulatory capture or strategic leniency of regulators, (6) an alternative identification approach using a regression discontinuity design, and finally (7) survivorship-bias concerns in our data.

\section{A.1 Assortative Matching}

We examine the idea of assortative matching. We examine the effect the transition in oversight had on changes in the probability of hiring an IAR with a past complaint, conditional on hiring. Table 1 presents our analysis. Across columns (1) to (6), we find evidence consistent with mid-size RIAs increasing hiring of representatives with past complaints. 
In columns (1) and (2) we control for the log number of hirers, and in columns (5) and (6) we normalize by the number of hires. We only control for state and year fixed effects given that we do not observe multiple repeated observations of the firm in a much reduced sample size. The statistical significance and coefficient estimates depend only slightly on the sampling window, but overall the message is clear: hiring of individuals with complaints increases in the years starting in 2012, just like our main effect. The totality of evidence may be weakly consistent with the notion that individuals, particularly those who have experience in the new regulatory environment, are more likely to gravitate toward a weak regulatory environment in the form of moving to a transitioned firm. However, we feel best to take a more measured approach.

\section{A.2 Re-Registration with the SEC}

Another concern is that some firms may re-register with the SEC. As assets under management increase (exogenously to the adviser or not) firms re-register with the SEC. If asset growth rates are random due to different factors unrelated to RIA quality, transitioning from SEC to state regulators or vice versa occurring after the implementation of the Dodd-Frank Act would attenuate our results. However, if the allocations and asset growth are related to the quality of investment advisers, our results would be biased.

There are two ways of thinking about treatment. On one extreme, we do not allow firms to re-register. On the other extreme, we allow firms to re-register, but we should treat the re-registration as exogenous. Otherwise, there may be the concern of manipulation. Of the transitioned RIAs, 350 switched back from the state regulator to the SEC at least one year after the implementation of Dodd-Frank. What led to switching in the post period may be problematic if RIAs manipulated AUM to operate under the RIA's preferred regulator. The market performance may lead to switching that is plausibly exogenous.

Therefore, we run two tests. We first try to show what happens to our pure reduced form results accounting for those who we know to later re-register. Second 


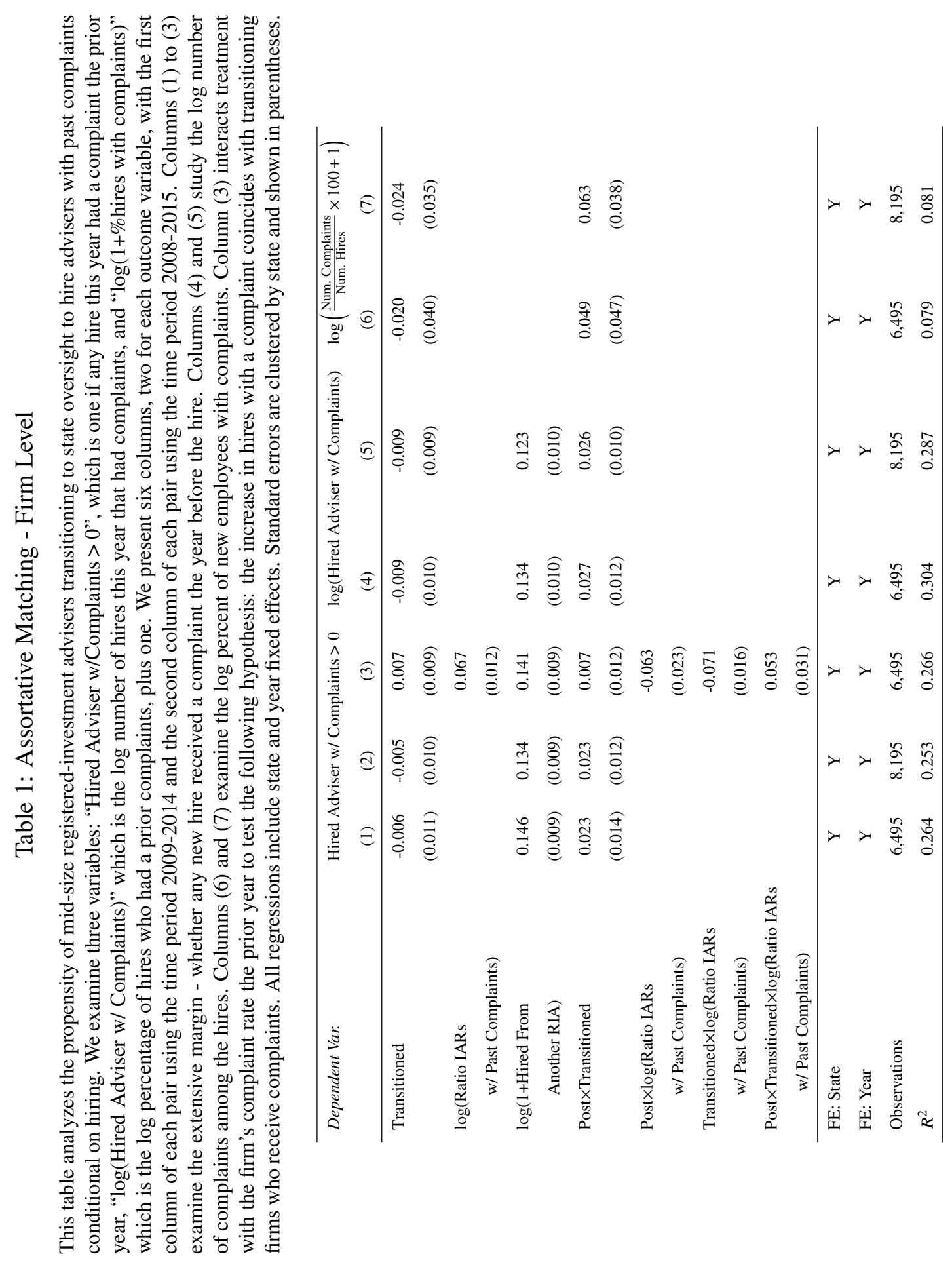


we try to instrument the re-registration among those who were originally transitioned. Our original test abstracted away from this concern by considering firms transitioned if once transitioned. However, when we started the project, we obtained an Investment Adviser Public Disclosure database compilation report which provides a daily refresh of the roster of investment advisers. The SEC does not archive historical daily versions, but we have the compilation report as of early 2015. This is important because we have a clear snapshot as of the start of 2015 as to who is SEC and who is state registered. Otherwise, we don't know the exact timing of re-registration because of various peculiarities with Form ADV. Our main concern would primarily be that significant confusion existed among de-registering advisers such that it becomes unclear to us when exactly a firm may have filed Form ADV again. Based on the results below, it would appear to work against us.

We then create a new dummy for re-registration with the SEC. We run a crosssectional test comparing those who originally transitioned to those who transitioned and then re-registered with the SEC as of the start of 2015. They may have reregistered in 2013 or 2014 . We expand our sample through to 2016 now to maximize the amount of data available.

Second, we run an instrumental variables regression. We run an IV for reregistration by 2015 captured by our variable "SEC Re-Registration". The instrumental variable is based on the state-level growth rates of assets under management from 2011 to 2014. Each firm is differentially exposed by its assets under management in 2011. There are three specifications. First, we calculate the overall growth rate of all AUM in the state, denoted by $g_{s}=\frac{\sum_{i \in s} A U M_{i, 2014}}{\sum_{i \in s} A U M_{i, 2011}}$ and construct a variety of Hausman-like instruments. In specification 1, we multiply the firm's 2011 AUM by the ratio of 2014/2011 AUM for that state. The first instrument QRANK $\left(g_{s} \times A U M_{i, 2011}\right)$ takes the quintile rank of this number. Second, QRANK $\left(g_{s} \times A U M_{i, 2011}\right)>0.8$ is an indicator variable for those who are in the 80th or above of percentile of projected AUM. Third, we use a three polynomial orders of $\log (A U M * g)$. Fourth, we use three polynomial orders of $A U M * g$. These last three specifications capture the tail-end of growth in AUM, which increases our power to identify the firms that grow due to exogenous state-level forces. Because there may be heterogeneity over this period across states that is unrelated to 
Dodd-Frank, we include state fixed effects. We believe these instruments are plausibly exogenous to a specific mid-size RIA firm since the market concentration at the state-level of a single firm is small. The SEC requires advisers to re-register if assets in a subsequent year exceed $\$ 110$ million. 


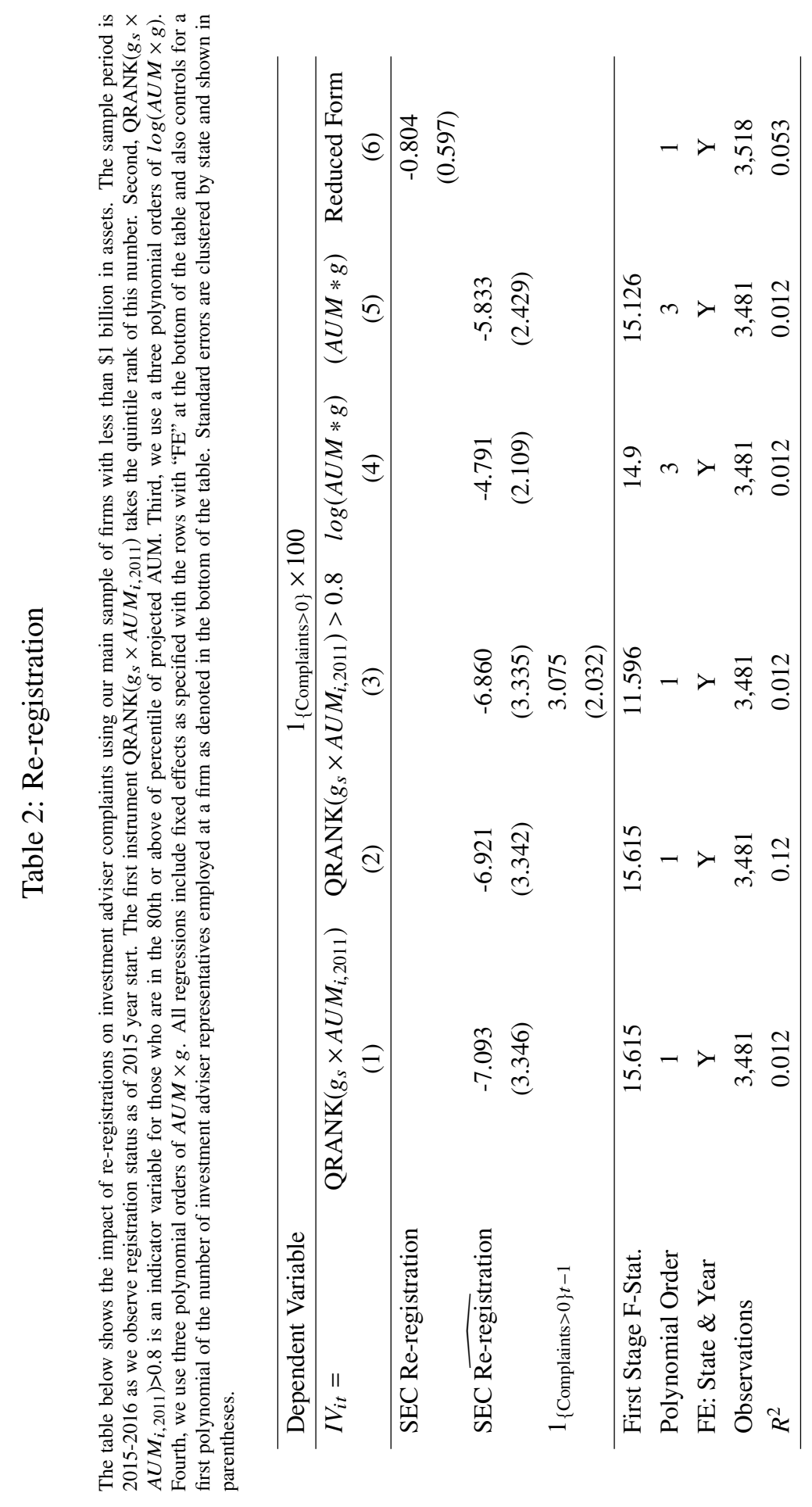


Table 2 below reports the results using the instrumental-variables specification. As this is a cross-sectional test, we remove firm fixed effects which would subsume treatment. The table shows that RIAs that re-register with the SEC see a reduction in complaint rates consistent with such advisers improving service quality in response to stronger oversight. We present three specifications. First we quintile rank the projected AUM growth. Second, we measure whether firms are in the 80th percentile or above. The next column adds the lagged complaints, exploring the referee's suggestion that lagged complaints could partly explain the re-registration. We do not believe our Hausman-like instruments are correlated with firm-specific news on complaints so we believe the exclusion restriction to be valid without considering complaints in the past. However, the overall inference is similar if we do. Our clustered first stage F-statistic ranges from 11.59 to 15.615, and inspecting the first stage reveals a negative relation between prior complaints and re-registration. Third we use three instruments, taking three polynomial orders of the $\log$ AUM. Fourth we take three polynomial orders of the instruments in millions. Finally we present the reduced form. The outcome variable is the extensive margin of complaints but it is similar to study instead the log number of complaints as the outcome variables. Across most specifications, the F-statistics for the chosen specifications are quite high, far above the suggested levels for weak instrument identification.

\section{A.3 Ease of Filing Complaints}

We also consider whether differences in the ease of filing complaints moderates the transition effects. We analyzed the complaint forms for all 50 states and Washington DC. We first examined the means of filing the complaint and found that 25 states use a web-based complaint form while 26 do not. We also find that 18 states have an email option, while 33 do not. Only 4 states have a Spanish version of their complaint forms, and there are no other language options available.

We next examined the information collected. All complaint forms ask for some level of personal and case-related information. To answer this question, we use variation in the page count of complaint forms as a proxy for the amount of information requested. The mean and median number of pages in the "complaint form" are 2.9 
and 3.0 respectively with a standard deviation of 1.75 pages. The longest complaint form is 9 pages (Arizona) and the shortest is 0 pages (Wisconsin), which simply invites citizens to send a letter about the complaint and any supporting documents.

We also assess how tailored the form is to securities-related complaints. A more-tailored form comes from the "securities division," while a less-tailored form comes from a more general governmental level like the attorney-general's office or a division with oversight of responsibility of banks and mortgages in addition to investment advisers. We find that 41 states have a focused form and 10 states do not.

In Table 3, across all specifications, we find some evidence that more difficulty with respect to filing a complaint actually attenuates our main effects. However, the data on state filing difficulty was collected as of July 2018 and may also be endogenous to the quality of the regulator. We would expect to find these results if higher quality regulators had an easier means of reporting, receiving, and consolidating complaints. In contrast, if the cost of filing affects the complaint behavior, we would have expected to find the opposite result, that states with easier filing procedures should have more complaints. These results are also consistent with the threat of a complaint being an effective deterrence of actual misconduct, analogous to the economics of crime literature that documents safer areas receiving fewer 911 calls. $^{31}$ However, the interactions in Table 3 with the transition effect after the Dodd-Frank Act implementation are not statistically significant.

\footnotetext{
${ }^{31}$ Our first interpretation is also consistent with the economics of crime literature that is concerned with the endogeneity of police quality and changes in reported crime.
} 


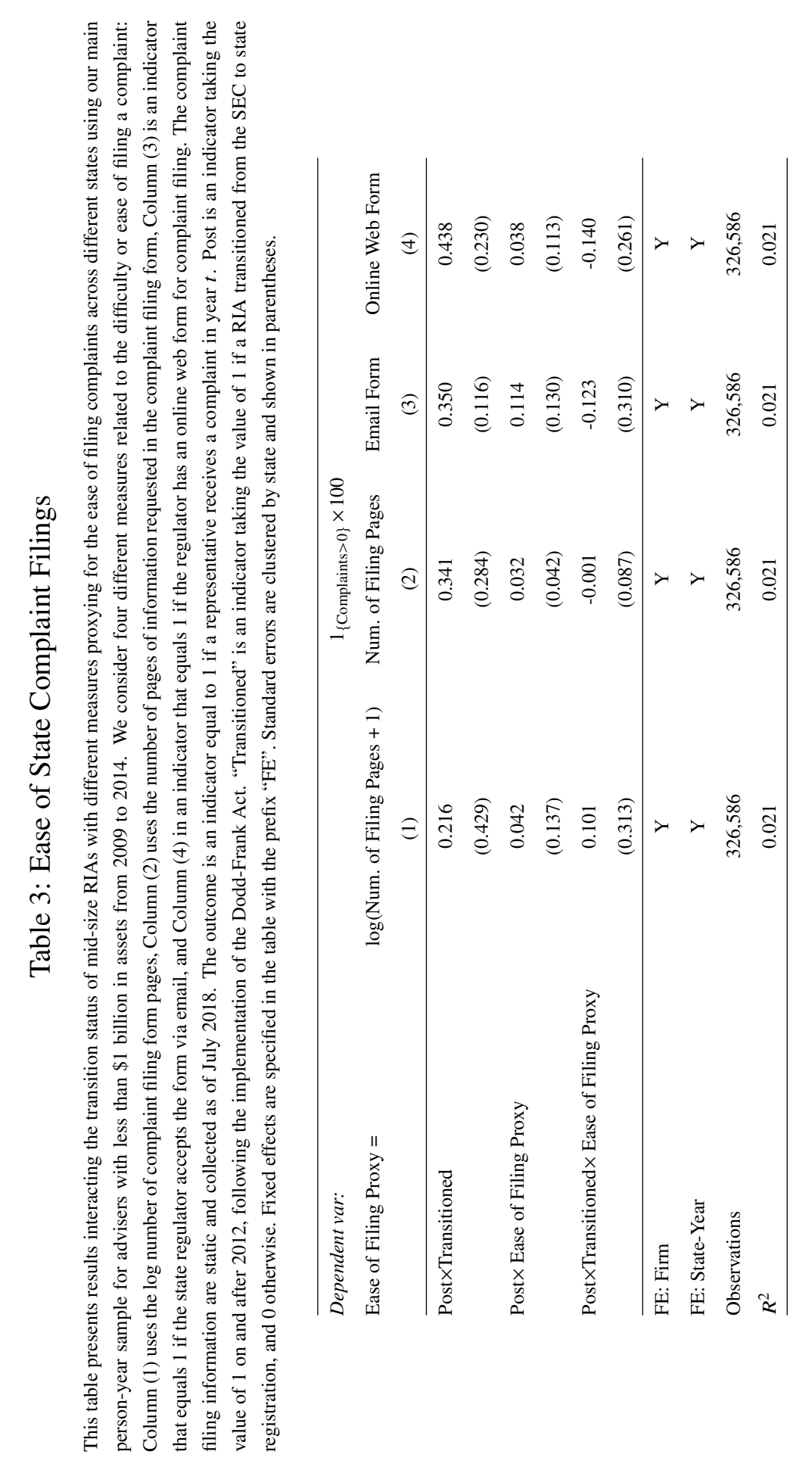


Another way to evaluate the content of the complaint forms is to look for mentions of certain topics. First, we search for the word "investment." We find that 35 states have forms using the word "investment" while 16 do not. Second, we look for the word "stock". We find 19 states have forms with the word "stock" while 32 do not.

In general, complaint forms ask for (1) the name of individual filing the complaint and address, (2) the name, phone number, and address of company invested money with, (3) which individual at the firm is involved, (4) a brief description of the complaint, (5) whether filed a complaint with the company or investment adviser and any response, and (6) whether filed a complaint with other state or federal agencies. Upon receiving a complaint, examiners will contact filers if they need any additional information. Usually, the examiners will also contact the firm/individual and give a chance for the firm/individual to respond. Regulators may then take no action, make sanctions, cancel license, or refer to court. All states conduct investigations keeping the identity of the individual filing a complaint confidential. However, information would be revealed publicly if ordered by the court. The agencies may send a copy of the complaint to the registered firm or individual.

\section{A.4 Alternative Complaint Measures \& Samples}

In Table 4, we find that our main treatment effects are robust to different scaling and transformations of the complaints outcome variable. In addition, these firm-level results persist after controlling for a cubic polynomial of the number of representatives that a firm employs.

In Table 5, we show that the parallel trends assumptions are met with these alternative outcome variable specifications. Our comparison group of mid-sized broker dealers is adjusted so that mid-size brokers start at the same level in 2006 as the transitioned RIAs. Otherwise mid-size advisers receive unconditionally much lower complaint rates, which may perhaps be attributed to a lack of conflicts-ofinterest between their roles as an adviser and broker. Perhaps due to rising equity markets in 2012 and 2013, many firms re-register some time in 2013. We find that if we remove firms that re-register with the SEC by early 2015, the parallel trends 
Table 4: Alternative Complaint Measures

This table presents firm-year level results to show the robustness under different transformations of our outcome variable using our main sample of firms with less than \$1 billion in assets for the sample period 2009 to 2014 . We show that the results are not sensitive to measures of complaints scaled by the number of advisers that a firm employs. In the regressions below, "Complaints" stands to the total number of complaints that a firm received in a year, and $N$ stands for the number of investment-adviser representatives employed at the firm. Column (1) uses the fraction of the total number of complaints scaled by the total number of employees, winsorized at the $98 \%$ level. Column (2) uses the log number of complaints plus one. Column (3) uses the log number of complaints scaled by 100 to show that the results are not driven by the "one-plus log" transformation. Post is an indicator taking the value of 1 on and after 2012, following the implementation of the DoddFrank Act. "Transitioned" is an indicator taking the value of 1 if a RIA transitioned from the SEC to state registration, and 0 otherwise. Fixed effects are specified below with the prefix "FE". Standard errors are clustered by state and shown in parentheses.

\begin{tabular}{|c|c|c|c|}
\hline Dependent Variable: & $\begin{array}{c}\frac{\# \text { Complaints }}{N} \times 100 \\
(1)\end{array}$ & $\begin{array}{c}\log (1+\# \text { Complaints }) \\
(2)\end{array}$ & $\begin{array}{c}\log (1+\# \text { Complaints } \times 100) \\
(3)\end{array}$ \\
\hline \multirow[t]{2}{*}{ Post $\times$ Transitioned } & 0.015 & 0.010 & 0.033 \\
\hline & $(0.007)$ & $(0.003)$ & $(0.015)$ \\
\hline \multirow[t]{2}{*}{$\log (N)$} & -0.198 & 0.016 & -0.176 \\
\hline & $(0.058)$ & $(0.037)$ & $(0.148)$ \\
\hline \multirow[t]{2}{*}{$\log (N)^{2}$} & 0.119 & -0.015 & 0.086 \\
\hline & $(0.030)$ & $(0.019)$ & $(0.075)$ \\
\hline \multirow[t]{2}{*}{$\log (N)^{3}$} & -0.012 & 0.008 & 0.010 \\
\hline & $(0.004)$ & $(0.003)$ & $(0.009)$ \\
\hline FE: Firm & $\mathrm{Y}$ & Y & Y \\
\hline FE: State-Year & $\mathrm{Y}$ & Y & Y \\
\hline Observations & 35,854 & 35,854 & 35,854 \\
\hline$R^{2}$ & 0.519 & 0.755 & 0.660 \\
\hline
\end{tabular}

graph shows a much stronger divergence. Between keeping and removing these firms, what we report is the more conservative of the two, which assumes firms never re-register with the SEC.

In Figure 2, we show the parallel trends graphs using the individual-level sample of representatives. In the paper, we feature similarly constructed graphs but using complaint rates aggregated to the firm level. 


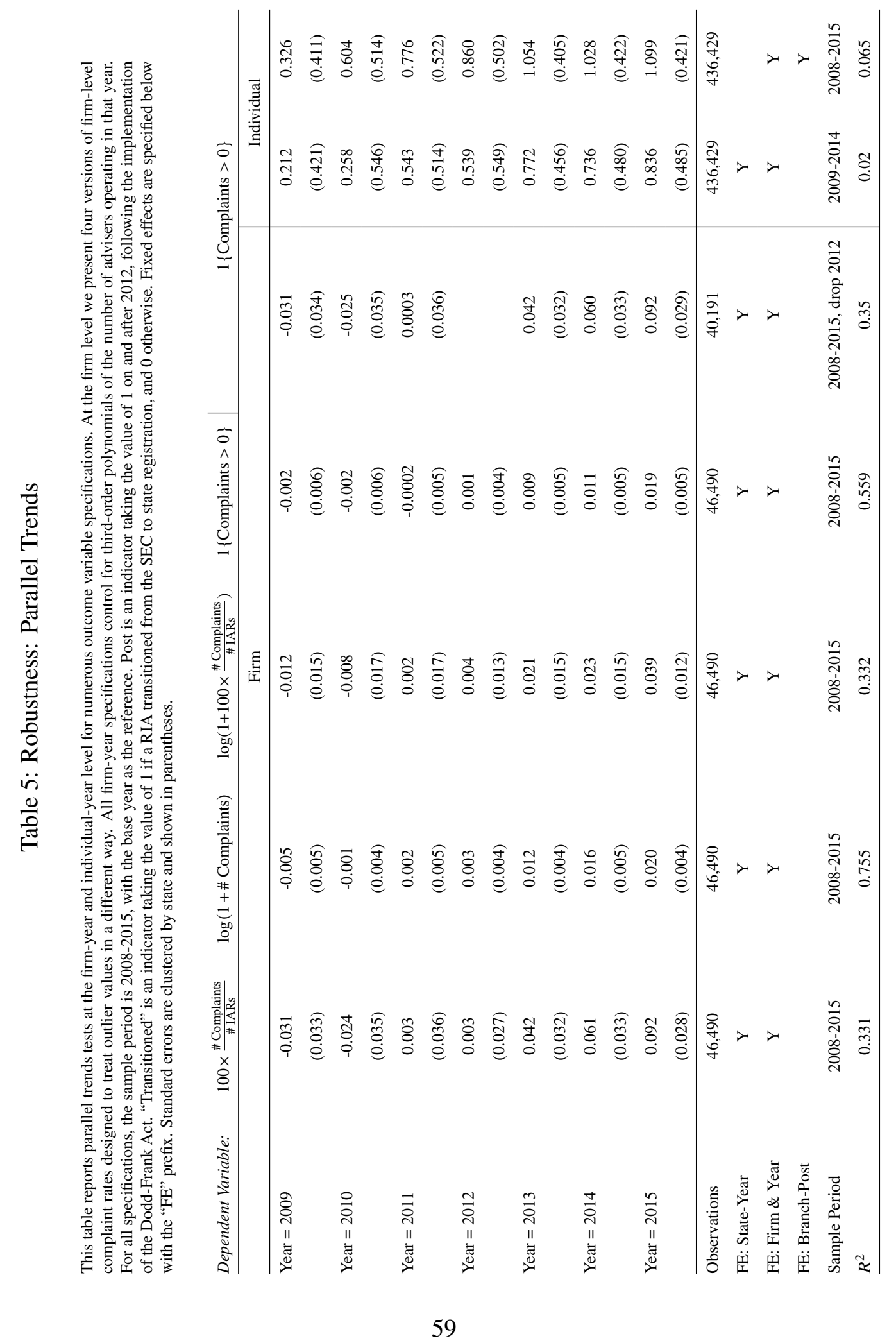


Figure 1: Additional Firm Level Parallel Trends 1

The figures below show the parallel trends for analyses at the firm level. Figure 3.1 adjusts the starting points of the mid-size broker-dealers in 2006 to be the same as the transitioned RIAs. One-standard error bands clustered by state are shown around the estimates.

(a) Mid-size Broker-Dealers

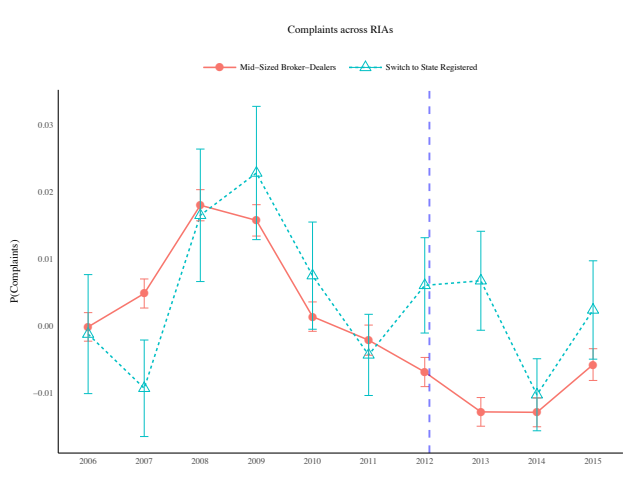

\section{A.5 Differing Reporting Requirements}

The first concern is a potential delay in when the complaint was received after the misconduct. That is, the increase in complaints could be explained by opportunistic clients if clients have a strategic incentive to delay filing complaints until their adviser transitions in 2012. Figure 2 helps dispel this alternative explanation. The gap in complaint rates between transitioned and non-transitioned advisers appears to persist through 2014, mitigating the alternative that complaints merely reflect a backlog. Cross-sectional evidence also casts doubt on this alternative. First, the states with lower staff-per-RIA had higher complaints, whereas states with capacity would likely accommodate any queue more effectively. Second, firms closer to the regulator saw fewer complaints, whereas these firms would likely be the firms most sought after by the regulator. Third, the less sophisticated investors are the least likely to be aware of regulator capacity, yet as clients of transitioned firms were the likeliest to complain.

A second alternative is that either the SEC has a more lax or a state regulator has a more stringent reporting standard for complaints. However, we believe this is not an issue for numerous reasons. We spoke with several regulators to confirm that 
Figure 2: Parallel Trends at the Individual Level

The figures below show the parallel trends for analyses at the individual level. Sub-Figure 3.1 shows the results for individuals working at firms with less than $\$ 1$ billion in assets under management as of 2011 , consistent with our main sample of analysis. Sub-Figure 3.2 shows the results for individuals working at firms with less than $\$ 500$ million in assets, which may permit a closer and more valid comparison between more similar firms between transitioned and non-transitioned firms. One-standard error bands clustered by state are shown around the estimates.

(a) Individuals in Firms with $\leq \$ 1$ billion in(b) Individuals in Firms with $\leq \$ 500$ million

AUM

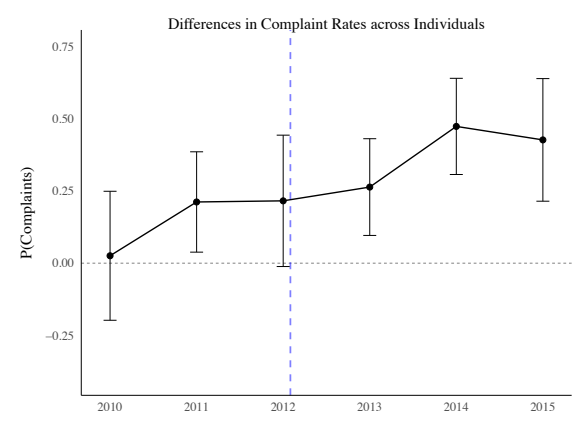

in AUM

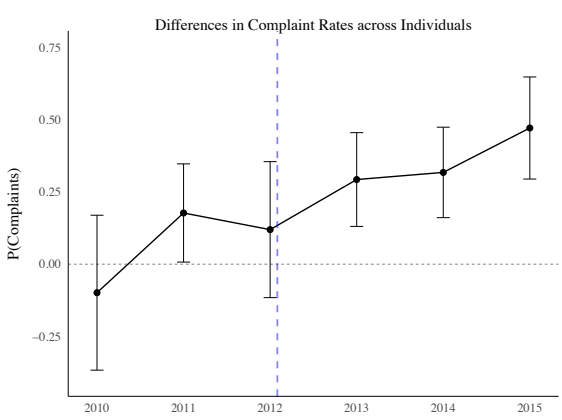

FINRA handles disclosure reporting. This allocation of responsibility suggests regulator involvement in expungement of records or the general reporting standards is likely not correlated with treatment. Also, to the extent regulator effort is required to intervene in the case of an expungement, for example, our forthcoming result suggests treatment is higher where regulators are less likely to be well-staffed. Moreover, we performed our analysis using data gathered in 2015 and 2016, achieving similar results. There is some delay between reporting a complaint and how long an adviser must wait to redact it. Finally, from inspecting the data by hand, often we actually observe cases that constitute cases that are no longer reportable, and have been asked by the adviser to be removed. In such cases, the complaint details (alleged damages and the case description, for example) are redacted, not the disclosure itself. Therefore, the extensive margin analysis is unlikely to be affected by these concerns. We a more detailed discussion in B.3. 


\section{A.6 Simulated Falsification}

We consider boot-strapped falsification tests based on randomizing treatment and comparison group assignments and years of treatment to test whether the estimated coefficients are statistically significant based on an empirical distribution of estimated treatment effects. The first approach preserves within-state and year effects while randomizing the cross section. The second approach preserves the crosssectional classifications into treatment and control but randomizes the time of implementation effects. Figure 3 shows that the estimated coefficients of treatment in our data are statistically significant well beyond the $1 \%$ level based on the histogram of 1,000 simulated samples and regression.

First, we randomly assign RIAs to the treatment group and show our estimated coefficient relative to a histogram of the simulated results. This preserves the state by year properties in the original dataset, but scrambles only the treatment and control group assignments in a way that preserves average unconditional treatment probability. Evidenced by the histogram, this random assignment eliminates the treatment effect.

Second, we randomly assign the years within each state and show the histogram of estimated coefficients. We find that our main effect is only statistically significant when the treatment year is 2012. Overall, both falsification exercises provide additional support that our estimated coefficients are indeed statistically significant even when simulating data that preserves within state correlations in complaints at a given point in time.

Finally, we also removed one state at a time. The distribution of coefficients is stable and the lowest coefficient we observed is almost as large as the original main effect.

\section{A.7 Local Economic \& Political Conditions}

If a state is experience high unemployment, the regulators may be more lenient in hopes to reduce regulatory burden on workers in the state in hopes to improve the local economic condition. Alternatively, they may also simply be distracted from their regulatory roles over investment advisers and instead focus on other concerns. 


\section{Figure 3: Histogram of Simulated $\hat{\beta}$}

The figure below shows the histograms of estimated coefficients from our main regression specification based on 1,000 simulations for each procedure. In the first procedure, we randomly assign treatment and control groups within each state and year so that the conditional probability of treatment in each state matches that in our main sample. In the second procedure, we replace the actual observed year with a randomly drawn year between 2009 and 2014 without replacement. For each simulation, we run a regression of the form 1 \{Complaint $\}_{i j t}=\alpha_{i}+\alpha_{j}+\alpha_{s t}+\beta_{1}$ Treated $_{j}+\beta_{2}$ Post $_{t}+\beta_{3}$ Post $_{t} \times$ Treated $_{j}+\varepsilon_{i j t}$ where $i$ is an individual adviser representative, $j$ is the registered-investment-adviser company, $s$ is the state, and $t$ is the year. Complaints stands for the number of total complaints that an RIA or IAR receives with a reporting or filing date within that year. Post is an indicator taking the value of 1 on and after 2012, following the implementation of the Dodd-

Frank Act. "Transitioned" is an indicator taking the value of 1 if a RIA transitioned from the SEC to state registration, and 0 otherwise. We cluster standard errors by state, allowing for RIAs and representatives within the same state to experience correlated shocks. Panel A shows the simulation based on randomly assigning treatment groups with the same probability as the unconditional treatment probability, among firms within the same state and year. Panel B shows the simulation based on randomly assigning years within each state and treatment group.

(a) Randomly Assigning Treatment and Controls within State and Year

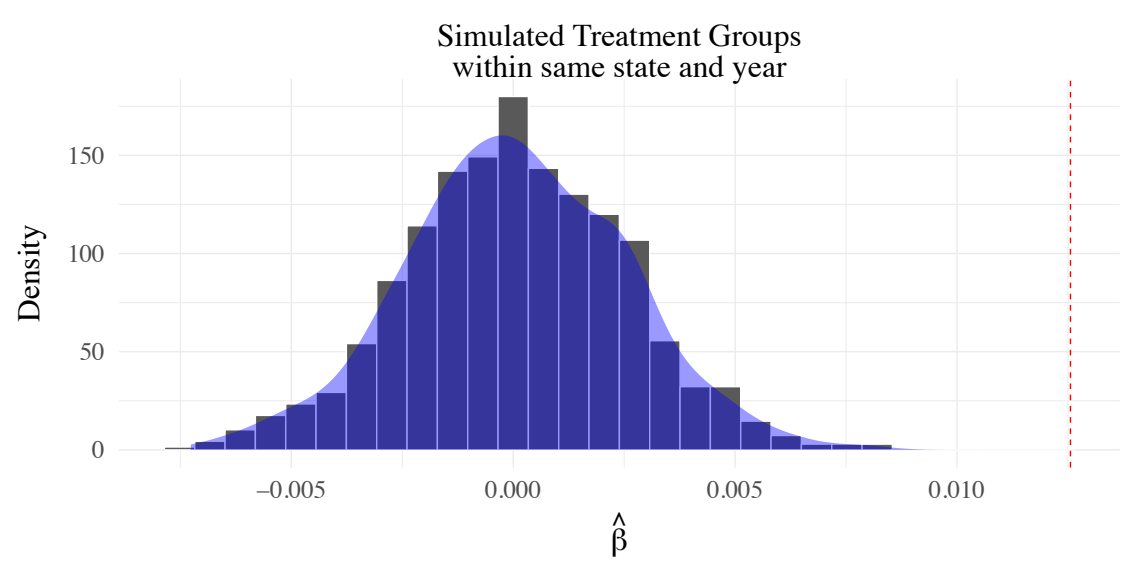

(b) Randomly Assigning Years within State and Treatment Group

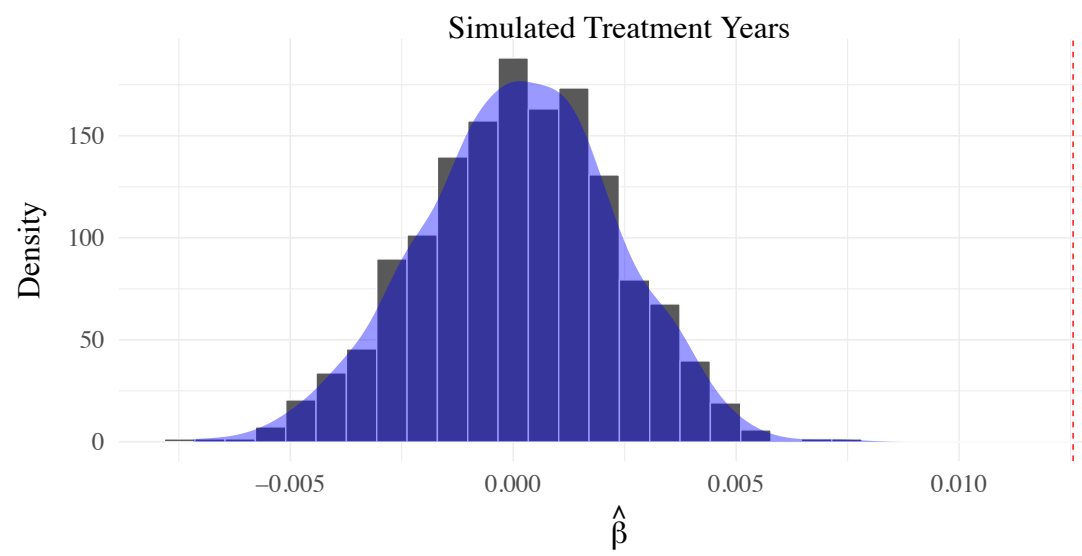


In Table 6 below, we explicitly consider the interaction of the transition effects with measures of local economic conditions. We estimate a specification of the form

$$
\begin{gathered}
1\left\{\text { Complaint }_{i j t}=\alpha_{t}+\alpha_{j}+\alpha_{s}+\beta_{1} \mathrm{X}_{t}+\beta_{2} \text { Post }_{t} \times \mathrm{X}_{t}+\beta_{3} \text { Transitioned }_{j}\right. \\
+\beta_{4} \text { Transitioned }_{j} \times \mathrm{X}_{t}+\beta_{5} \text { Post }_{t} \times \text { Transitioned }_{j} \times \mathrm{X}_{t}+\varepsilon_{i j t}
\end{gathered}
$$

where $j$ is the registered investment adviser company, $s$ is the state, and $t$ is the year. $\mathrm{X}_{t}$ captures lagged state-GDP growth, lagged state unemployment, countylevel loan-to-value ratios of mortgages from the ACS 2011, county-level fraction of households with mortgages from the ACS 2011, and county-level homeownership percentage from the ACS 2011. We cluster standard errors by state, allowing for RIAs and representatives within the same state to experience correlated shocks.

Unlike in the main tables in our paper, we do not include state-year fixed effects since we are striving to test whether state-year level variables interact with the transition effect. There may be better measures of local economic conditions worth looking at. Among the array of measures we examined, we generally find no statistically significant evidence of local economic conditions moderating the transition effect at the $10 \%$ level. Nevertheless, interpreting the coefficients would suggest that the divergence in complaint rates was slightly larger in areas with previously lower-GDP growth, higher unemployment, lower-home ownership, and areas with less mortgages. We find no relation between the local loan-to-value and transition effects. These measures of local economic conditions likely influence the regulatory resources of the state regulators. Areas with more economic distress may be less likely to increase budgets for state-securities regulators, which motivates including state-year and even branch-post fixed effects in our specifications.

In Table 7, we examine directly whether the transition effect varies with preferences for democratic governors measured by voting share and also with whether the governor faces an upcoming election. In Table 7, we first consider differences across states in the state's governor's political affiliation. Perhaps, republican governors are more pro-business and thus easier to capture. However, another possibility is that republican governors simply prefer smaller governments and thus provide 


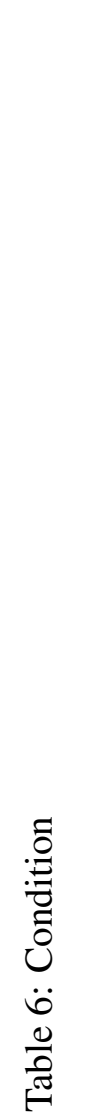

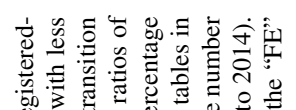
ఏ

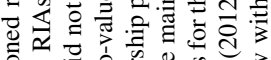

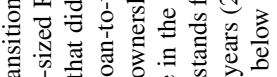
ut In ming my min ty En

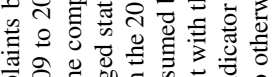

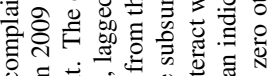

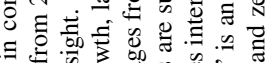
my

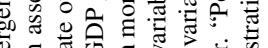

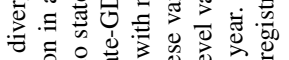

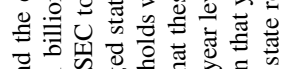

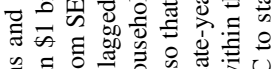

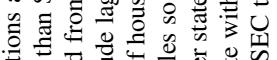

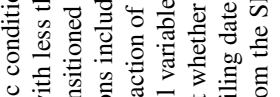

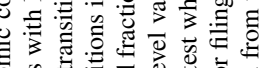

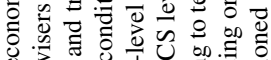

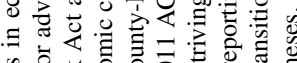

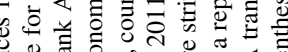

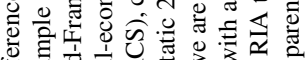

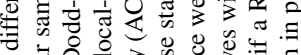

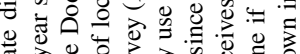

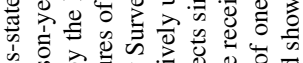

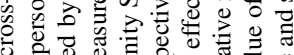

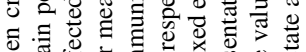

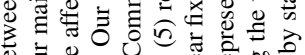

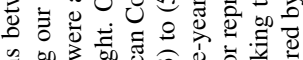

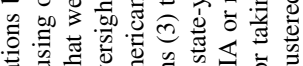

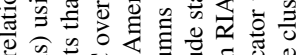

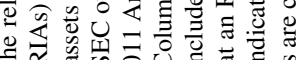

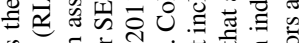

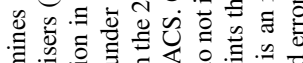

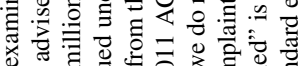

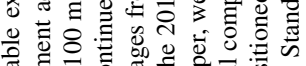

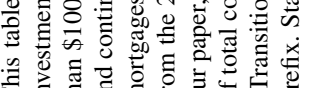

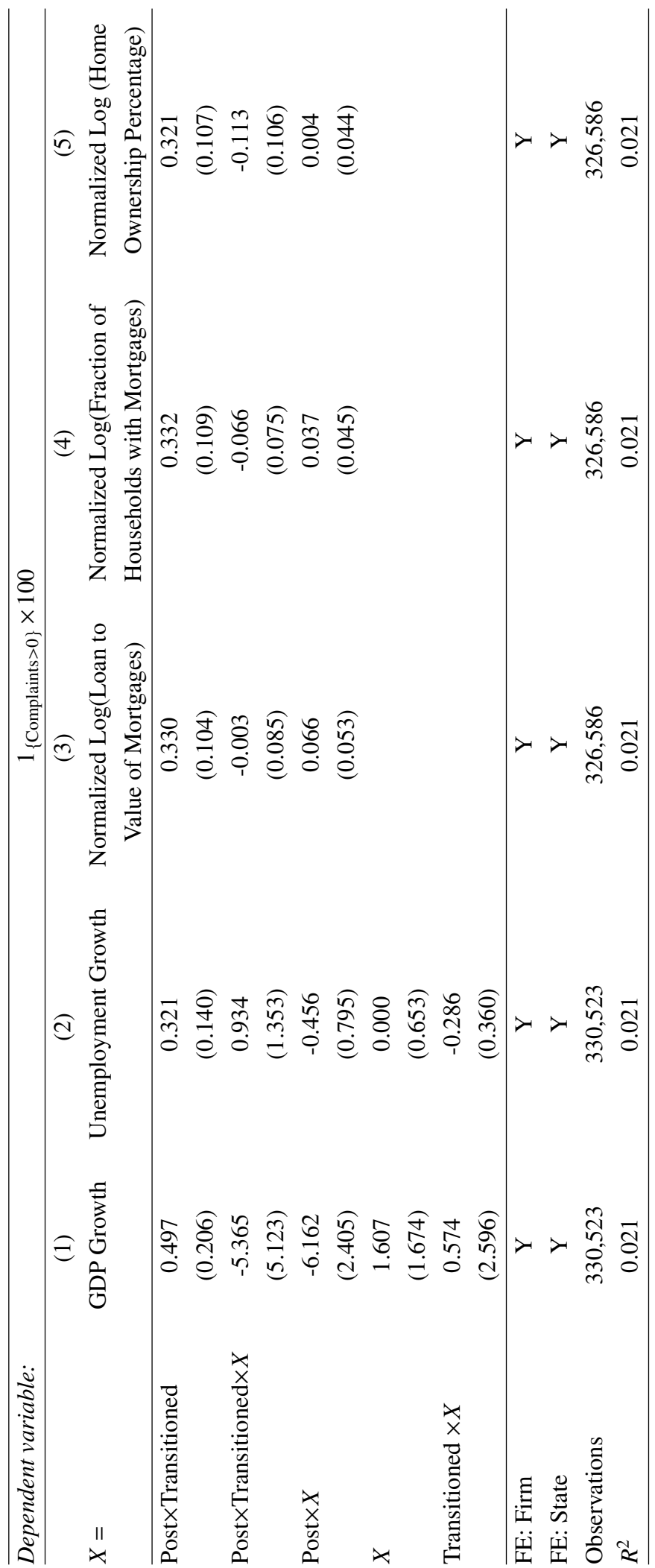


less funding to the state regulator, weakening the regulator. We find no relation between political affiliation and the effect of the transition.

Next, we analyze the effect of elections. Our first caveat is that elections tend to cluster in time. Specifically, for each of the years from 2009 to 2015, there were $\{2,39,4,12,2,38$, and 3$\}$ elections respectively. That is, 38 elections in the year 2014, when our effect is the greatest. Thus, we caution against the reader from interpreting this too closely. With this caveat in mind, column (4) indicates that if an election is this year or next, we see more complaints, significant at the $5 \%$ level. This indicates if anything the opposite of political capture. If we were to interpret this evidence aggressively, it appears the government is more heavyhanded against investment advisers, leading to more complaints, during years of elections. If anything it appears the opposite appears to be true. This test helps us isolate differences in our setting versus that of Agarwal et al (2014). We have posited that one crucial difference between our paper and Agarwal et al (2014) is the absence of political capture in our setting and the commonality of local interests in both settings. This test helps us directly rule out that our results are due to political capture. Also, in our setting, financial constraints matter if regulators want to protect clients of advisers whereas they would be more lenient for clients of commercial banks which requires less resources.

\section{A.8 Regression Discontinuity Approach}

To further alleviate concerns about the control groups being different, we also implement a regression discontinuity design (RDD) to identify the impact of the regulation. Figure 4 shows using a narrow sample of firms around the $\$ 100$ million threshold a similar increase in complaints for transitioned firms after the transition. By narrowing the sample to only those RIAs with assets very close to the $\$ 100 \mathrm{M}$ threshold, we reduce the possibility that these RIAs are different. The discontinuity identification generates the same qualitative and quantitative results, albeit at a loss of some statistical power due to limited sample availability around the discontinuity threshold of $\$ 100$ million.

The RDD design is not ideal for our setting because AUM shifts from 2011 
Table 7: Impact of Democrat vs. Republican Governors

This table examines the relation between the transition effect and governor political affiliations and also whether the governor faces an upcoming election using our main person-year sample for advisers with less than $\$ 1$ billion in assets from 2009 to 2014. The outcome variable "Normalized Democrat-Republican Gap" captures the normalized difference in vote share of the democratic governor in the state election. The outcome variable "Election ( $\mathrm{t}$ )" is an indicator that equals 1 if the state has a governor election in year $t$. "Election $(\mathrm{t}+1)$ " is an indicator that equals 1 if the state has a governor election in year $t+1$. "Election $(\mathrm{t}, \mathrm{t}+1)$ " is an indicator that equals 1 if the state has a governor election either in year $t$ or $t+1$. We use our main sample of investment adviser firms with less than \$1 billion in assets from 2009 to 2014. The comparison group are firms not directly affected by the transition, namely those with more than $\$ 100$ million in assets and also mid-size RIAs in New York and Wyoming which remained under SEC oversight. Complaints stands for the number of total complaints that an RIA or IAR receives with a reporting or filing date within that year. Post is an indicator taking the value of 1 on and after 2012, following the implementation of the Dodd-Frank Act. "Transitioned" is an indicator taking the value of 1 if a RIA switched from the SEC to state registration, and 0 otherwise. Fixed effects are specified below with the "FE" prefix. Standard errors are clustered by state and shown in parentheses.

\begin{tabular}{lcccc}
\hline Dependent variable: & \multicolumn{4}{c}{$1_{\{\text {Complaints }>0\}} \times 100$} \\
\hline \multirow{2}{*}{$X_{t}=$} & $\begin{array}{c}\text { Normalized } \\
\text { Democrat-Republican Gap }\end{array}$ & $\begin{array}{c}\text { Election } \\
\mathrm{t}\end{array}$ & $\begin{array}{c}\text { Election } \\
\mathrm{t}+1\end{array}$ & $\begin{array}{c}\text { Election } \\
\mathrm{t}, \mathrm{t}+1\end{array}$ \\
\hline Post $\times$ Transitioned & 0.320 & 0.194 & 0.226 & 0.044 \\
& $(0.109)$ & $(0.124)$ & $(0.123)$ & $(0.142)$ \\
Transitioned $\times X_{t}$ & -0.015 & -0.116 & 0.163 & -0.273 \\
& $(0.051)$ & $(0.185)$ & $(0.168)$ & $(0.123)$ \\
Post $\times$ Transitioned $\times X_{t}$ & -0.017 & 0.268 & 0.163 & 0.393 \\
& $(0.109)$ & $(0.230)$ & $(0.168)$ & $(0.148)$ \\
\hline FE: Firm & $\mathrm{Y}$ & $\mathrm{Y}$ & $\mathrm{Y}$ & $\mathrm{Y}$ \\
FE: State-Year & $\mathrm{Y}$ & $\mathrm{Y}$ & $\mathrm{Y}$ & $\mathrm{Y}$ \\
Observations & 330,523 & 330,523 & 330,523 & 330,523 \\
$R^{2}$ & 0.021 & 0.021 & 0.021 & 0.021 \\
\hline
\end{tabular}


to 2012 (particularly with the bull market in the latter half of 2011), and we only observe AUM reliably for SEC-registered RIAs, not state-registered RIAs. Also, some firms are disqualified from state registration for other reasons even if managing less than $\$ 100$ million. Therefore, our current setup relies on indications provided by the firm or a regulator that the adviser transitioned to state jurisdiction. With these caveats in mind, we try our RDD design with a \$10-million-AUM bandwidth around either side of the \$100-million threshold. We use a registeredinvestment adviser's 2011 AUM and require the adviser to be headquartered in the 48 states affected by transition (i.e. not New York or Wyoming). In the post-period, we find weak statistical evidence that being below $\$ 100$ million in assets leads to higher numbers of complaints. This effect appears to be absent in the pre-period, but the evidence is suggestive because of the difficulty of classifying firms using purely lagged AUM.

\section{A.9 Sample Survivorship Bias Concerns}

In this section, we directly test whether advisers are more likely to leave our sample after receiving a complaint. There is no significant evidence that representatives working for transitioned mid-size RIAs are more or less likely to leave the industry upon getting a complaint. If anything, representatives working for transitioned mid-size RIAs and receiving a complaint are less likely to see their ultimate year, consistent with weaker regulators who are less likely to terminate those with complaints.

\section{A.10 Workload Shock}

This section discusses our results on the workload of regulators. We take the number of people/firms who we presume to be under state jurisdiction and the percentage change based on the number of transitioning firms in $2012 .{ }^{32}$

\footnotetext{
${ }^{32}$ If a firm is under SEC jurisdiction they must file form ADV with the SEC. Firms which do not register with the SEC do sometimes file anyway with the SEC, either hoping to gain visibility or as a signal to consumers. In any case we presume a firm is not registered with the SEC in 2011 if
} 


\section{Figure 4: Regression Discontinuity Plots}

The figures below show the average number of complaints of firms in \$1 million dollar bins using the main sample from 2009 to 2014 , but include only firms whose size are between $\$ 75$ million and $\$ 125$ million, tightening the bandwidth to improve precision around the $\$ 100$ million threshold. We split the panel into before and after 2012 , when the Dodd-Frank Act was implemented.
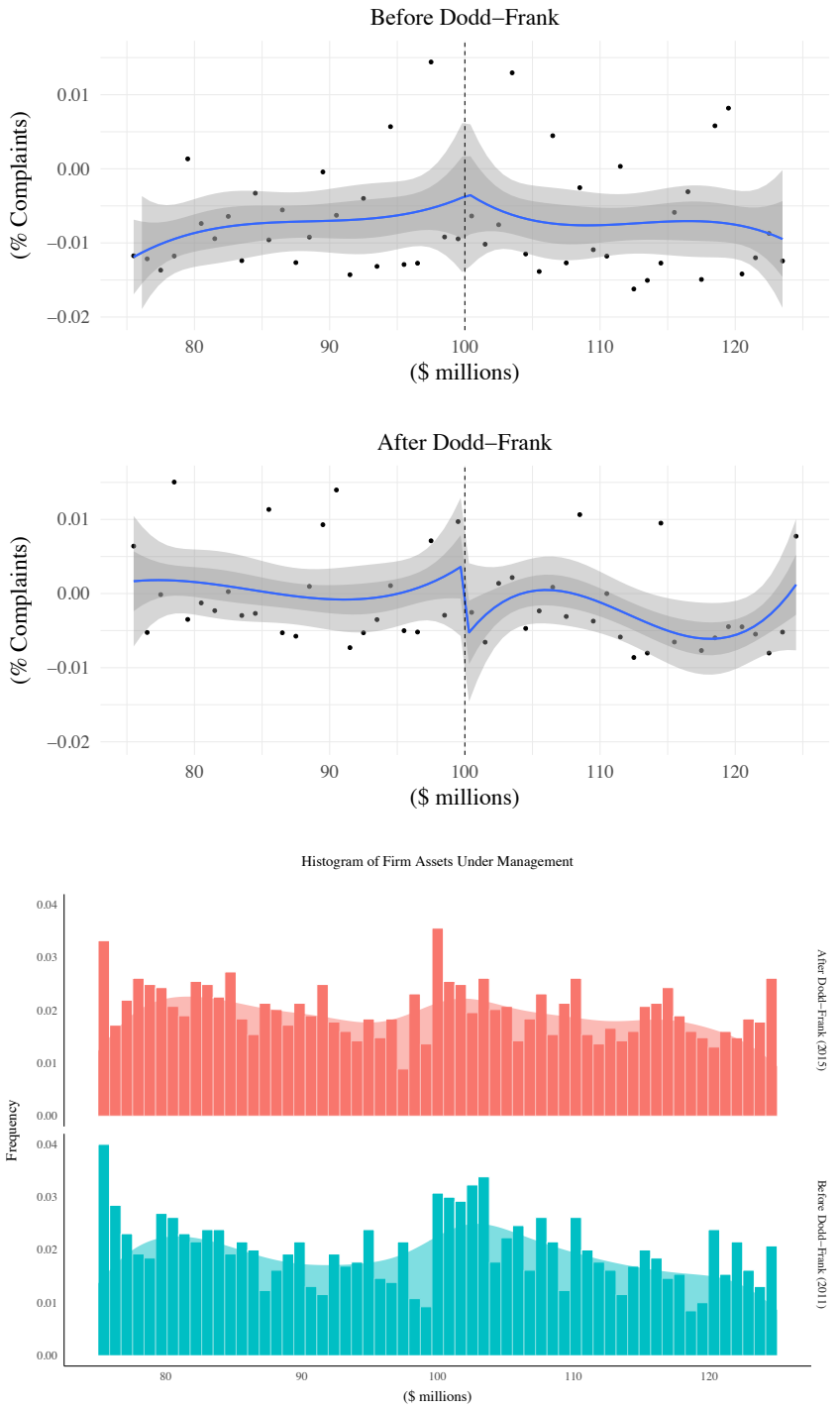
Table 8: Investment-Adviser Representative Exits

The table below shows the probability that an investment-adviser representative drops out of our sample after receiving a complaint using our main person-year sample for advisers with less than \$1 billion in assets from 2009 to 2014 . The dependent variable Penultimate $t_{t}$ takes the value 1 if year $t$ is the penultimate year a representatives exists in our sample. The dependent variable Ultimate $t$ takes the value 1 if year $t$ is the last year an IAR exists in our sample, limiting it to end in 2014. Complaints stands for the number of total complaints that an RIA or IAR receives with a reporting or filing date within that year. Post is an indicator taking the value of 1 on and after 2012, following the implementation of the Dodd-Frank Act. "Transitioned" is an indicator taking the value of 1 if a RIA transitioned from the SEC to state registration, and 0 otherwise. Receiving a complaint is related to dropping out of our sample. Standard errors are clustered by state and shown in parentheses.

\begin{tabular}{lcc}
\hline Dependent variable: & Ultimate Year & Penultimate Year \\
\hline Post $\times$ Transitioned & $(1)$ & $(2)$ \\
\multirow{2}{*}{ Post $\times 1_{\{\text {Complaints }>0\}}$} & $(0.023$ & 0.0004 \\
& 0.009 & $(0.006)$ \\
$1_{\{\text {Complaints }>0\}}$ & $(0.007)$ & -0.006 \\
& 0.008 & $(0.007)$ \\
$1_{\{\text {Complaints }>0\}} \times$ Transitioned & $(0.003)$ & 0.006 \\
& 0.025 & $(0.006)$ \\
Post $\times$ Transitioned $\times 1_{\{\text {Complaints }>0\}}$ & $(0.020)$ & -0.030 \\
& -0.068 & $(0.025)$ \\
Observations & $(0.042)$ & 0.016 \\
$R^{2}$ & 330,451 & $(0.028)$ \\
\hline
\end{tabular}


Table 9 columns (1) to (4) perform extensive margin analysis at the individual level using two measures of workload changes. Columns (1) and (2) rank states by the percent change in number of firms and percent change in number of people in 2012. Columns (5) and (6) perform extensive margin analysis on the firm level using the log percent of firms (column 5) and log percent of people who transitioned over (column 6). Columns (7) and (8) take the log percent of people who transitioned to state oversight and perform the analysis on two other outcome variables: the log percent of employees who have complaints and the log number of complaints received by the firm. All firm-level specifications control for three polynomial orders of the number of people at the firm. Moreover, all specifications include firm and state-year fixed effects.

The results provide some evidence that changes in complaint rates can be explained by the number of people who transition. Columns (1) and (3) indicate an unreliable relation between complaint rates and the number of firms that transitioned. The relationships are positive but statistically unreliable with standard errors much larger than coefficients. However, columns (2) and (4) indicate that the number of people who transitioned is related to the increase in complaints. We believe the number of adviser representatives better represents the workload shock than the number of firms as it better conveys the true economic footprint of the firm and thus the burden the regulator may face. The base effect of treatment (post times treated) turns to zero or negative in these specifications, suggesting that workload may play a large role. We find a similar result at the firm level. Columns (6) to (8) indicate that the number of people transitioning is positively related to the increase in complaints, using firm-level data. However, this overall piece of evidence is statistically weaker than the main resource-constraint measures we provided above.

the firm never files an ADV in 2010, 2011 or 2012 with the SEC. 


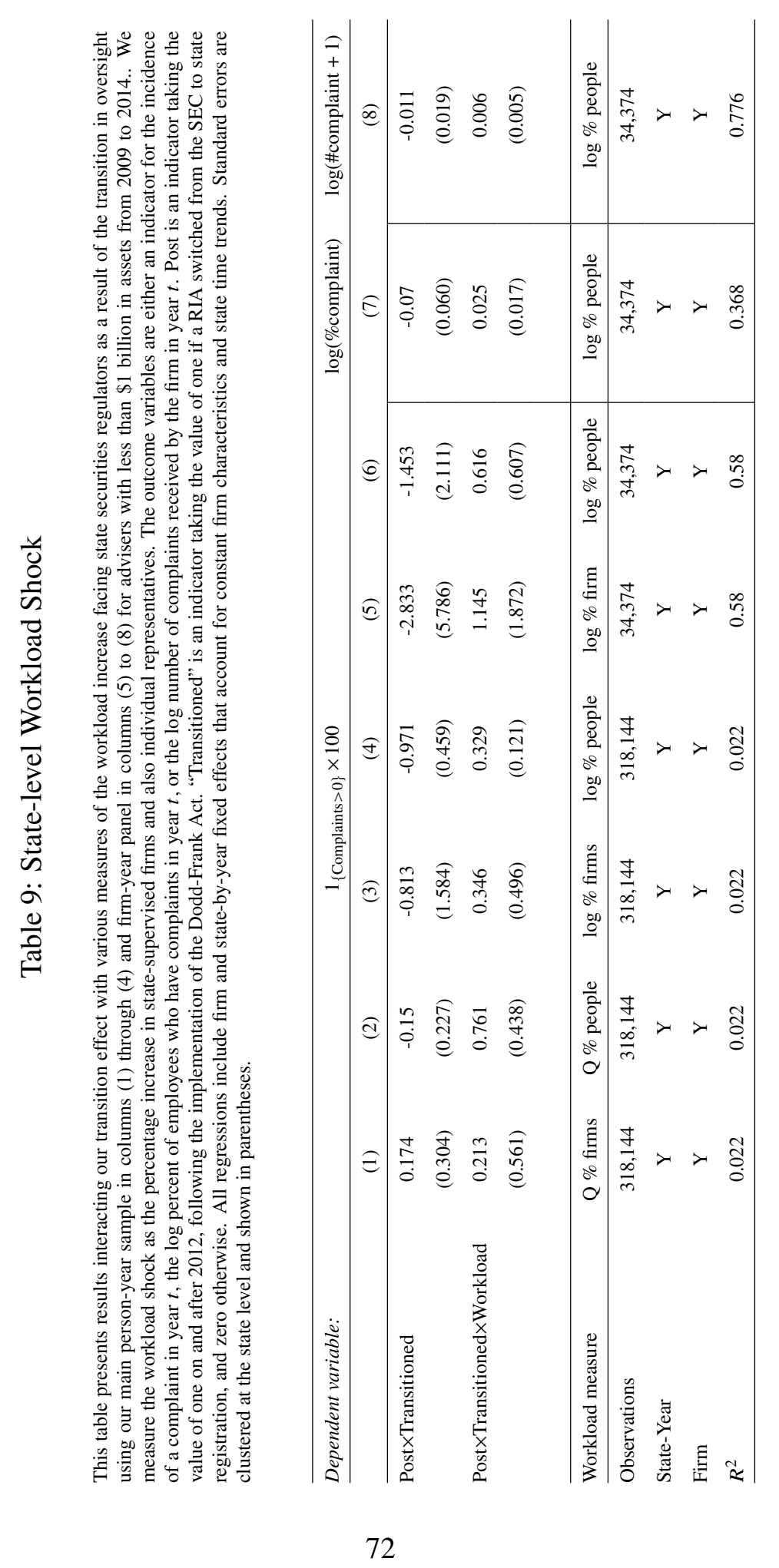




\section{B Additional Institutional Details}

In this section, we provide additional details on our setting. Figure 5 shows the total assets of the industry from 2001 through 2014.

Figure 5: Assets Growth

This graph presents the growth in assets under management of RIAs filing Form ADV to the SEC through 2014. We retrieved the ADV data from the SEC through a Freedom of Information Act request in 2015. For each RIA, we use the latest filing in the calendar year. Note that the AUM of mid-size RIAs is not included after the transition because mid-size RIAs no longer file a Form ADV with the SEC.

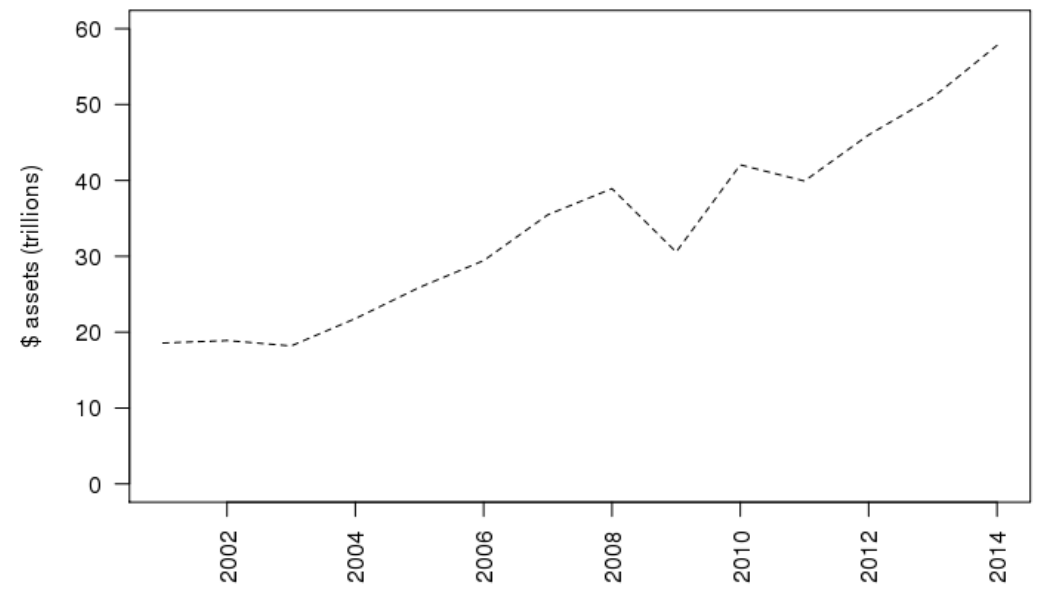

To provide additional color to the Form ADV data we acquired through the Freedom of Information Act, Table 10 shows a sample of available information. We provide firm-level summary statistics in Table 11 for this full sample, from which we construct our main data sample.

In Figure 6 we show that the annual time series filings of Form ADV-W to de-register with the SEC was stable before 2012 and recovered back to normal after 2014. To illustrate the CRD depository, which provides us the data through 


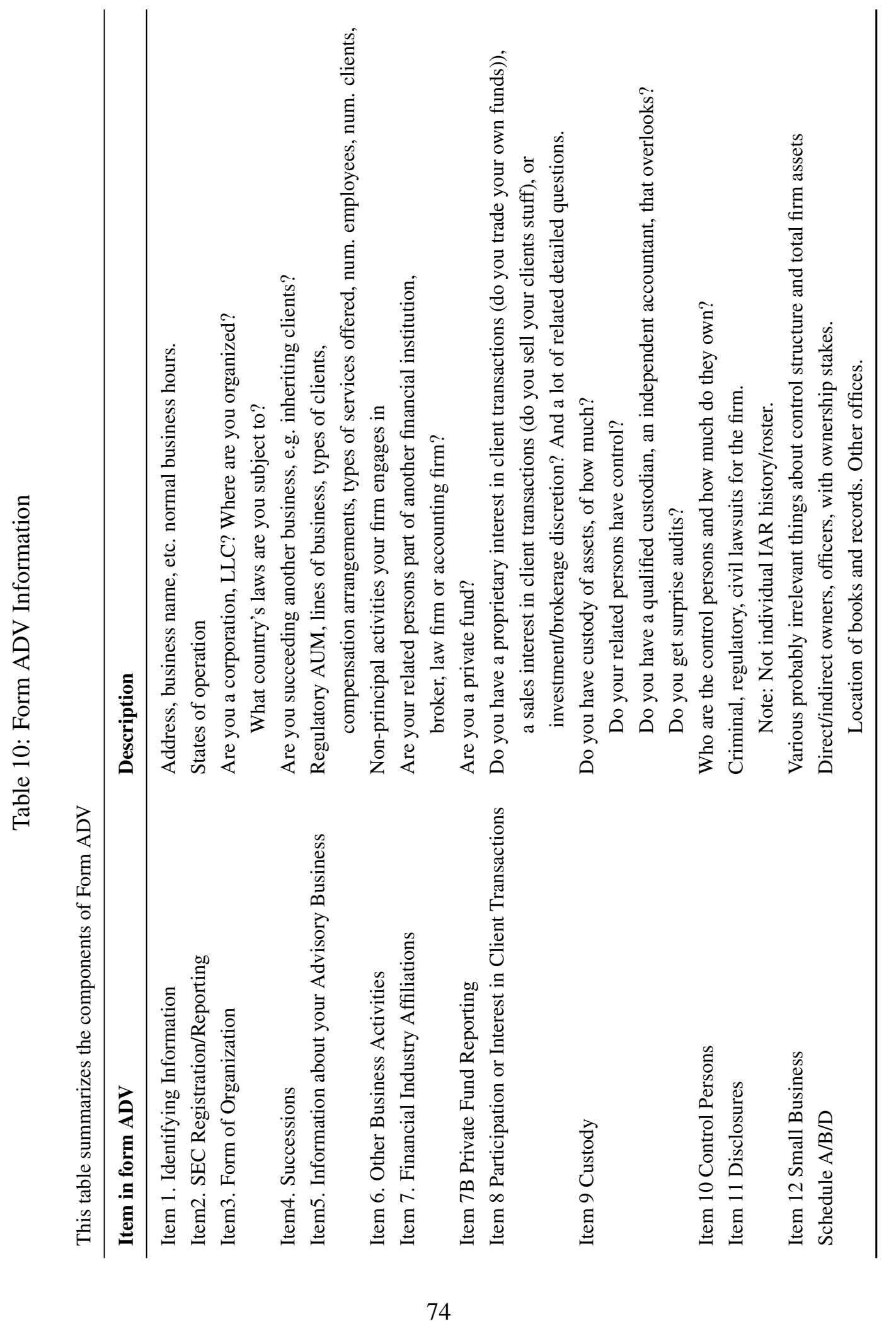


Figure 6: Annual ADV De-registration Filings

The graph below shows the number of RIAs that de-registered from the SEC with form ADV-W filings. The Dodd-Frank Act came into effect in 2012. "ADV-W Filings" refers to the total number of filed Form ADV-Ws. "Partial de-registration" presents the number of Form ADV-Ws with a "partial de-registration" description in the optional reason s. "\# Mention state de-registration" indicates how many partial de-registrations specifically mentioned the intention to register with state securities regulator.

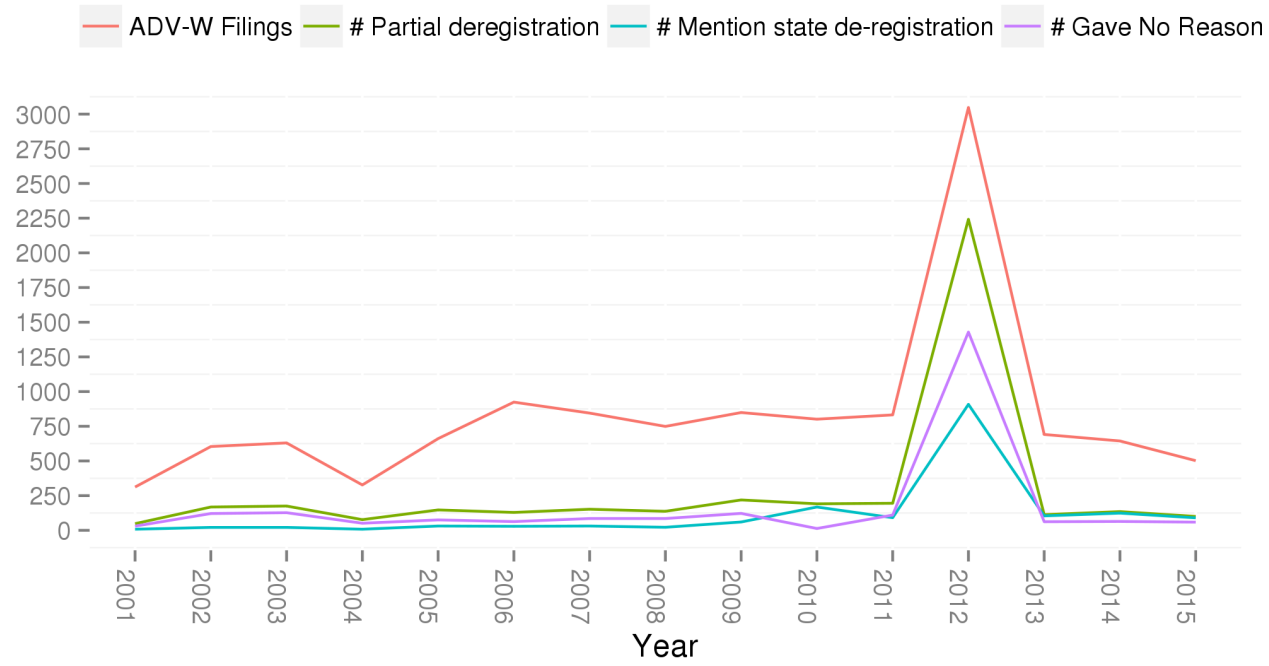

BrokerCheck and IAPD databases, we included the following schematic. The data infrastructure is shown the data infrastructure from different sources in Figure 7. We show a sample filing procedure from New Jersey in Figure 8, to show an example of a web form that investors can use to lodge an official complaint that we would observe in the data. 


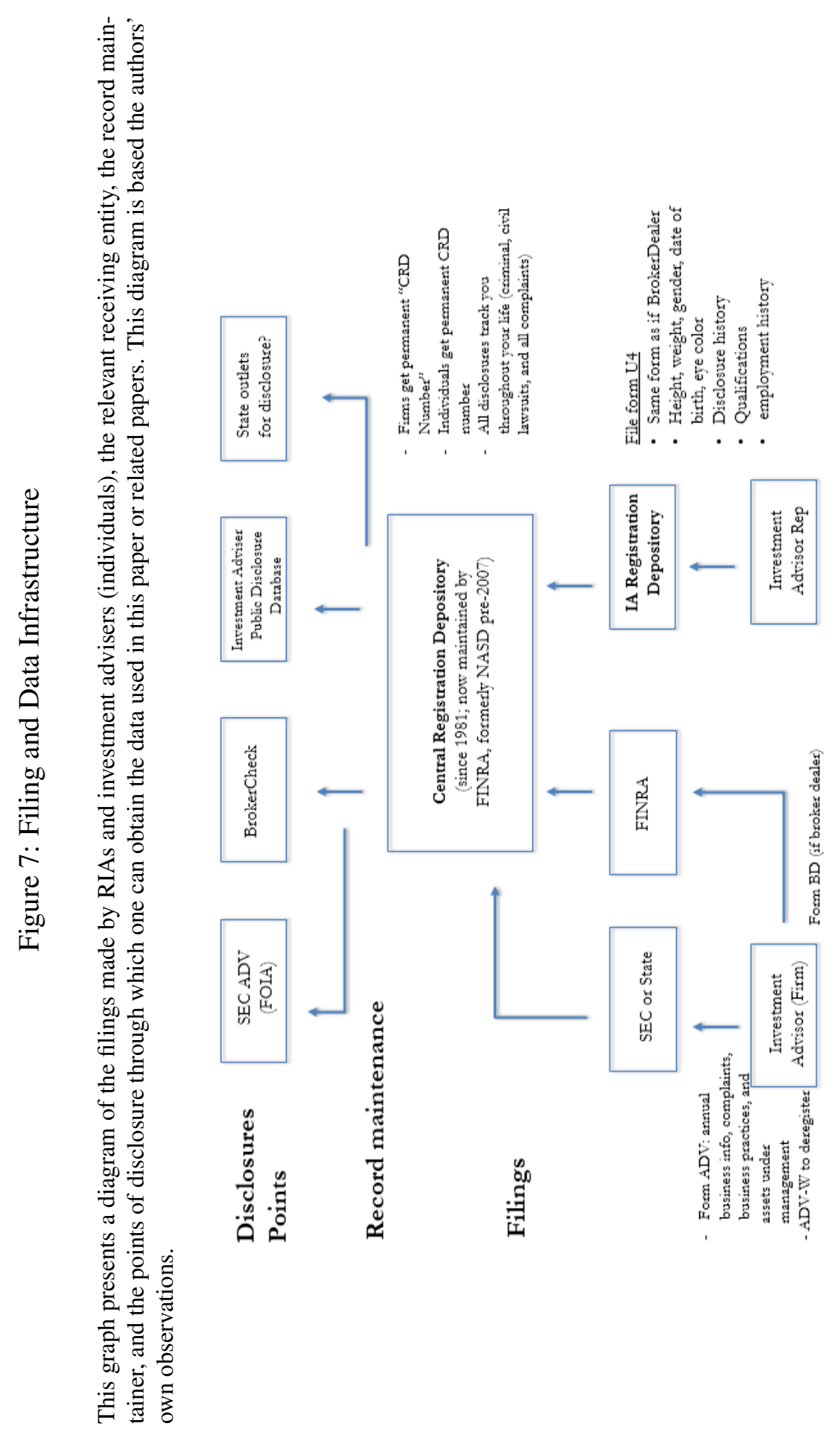


Table 11: RIA Summary Statistics for the Full Data

The table provides summary statistics for investment adviser RIAs from Form ADV filings for 2011, without placing the restriction of having less than $\$ 1$ billion in AUM. RIAs report whether they have custody over assets, independent audits, specific incentive structures, and report the fraction of clients who are institutions, private funds, government, and individuals. Advisers also denote whether individuals are accredited, earning either more than $\$ 200,000$ if single or $\$ 300,000$ if married, or more than $\$ 1,000,000$ in net worth. We denote accredited advisers as sophisticated. Funds are labeled as having a majority of clients in a particular category if the fraction of clients for the adviser is greater than or equal to $50 \%$.

Total Non-transitioned Transitioned

\begin{tabular}{|c|c|c|c|}
\hline AUM $10^{t h}$ Percentile & 35 & 103 & 30 \\
\hline AUM $25^{\text {th }}$ Percentile & 57 & 143 & 39 \\
\hline AUM 50 ${ }^{\text {th }}$ Percentile & 128 & 295 & 53 \\
\hline AUM $75^{\text {th }}$ Percentile & 422 & 882 & 72 \\
\hline AUM $90^{\text {th }}$ Percentile & 1,841 & 4,090 & 89 \\
\hline Fraction of AUM with Custody (\%) & 7 & 6 & 14 \\
\hline Fraction of RIAs with Custody (\%) & 18 & 24 & 8 \\
\hline Fraction with Independent Audits (\%) & 21 & 29 & 9 \\
\hline \multicolumn{4}{|l|}{ Incentive Structure: } \\
\hline Private Fund (\%) & 26 & 32 & 15 \\
\hline Other Business (\%) & 16 & 15 & 18 \\
\hline Other Business is Main Business (\%) & 5 & 5 & 6 \\
\hline Recommends a Broker (\%) & 64 & 68 & 58 \\
\hline Have Proprietary Conflicts of Interest (\%) & 87 & 88 & 86 \\
\hline Have Sales Conflicts of Interest (\%) & 20 & 27 & 10 \\
\hline Have Investment Discretion (\%) & 93 & 94 & 90 \\
\hline \multicolumn{4}{|l|}{ Client Composition: } \\
\hline Individuals (\%) & 69 & 66 & 75 \\
\hline Unsophisticated Individuals (\%) & 35 & 29 & 45 \\
\hline Institutions (\%) & 43 & 47 & 36 \\
\hline
\end{tabular}


Table 12: Total Data Observation Counts

\begin{tabular}{lr}
\hline \multicolumn{2}{c}{ Observation Counts } \\
\hline Unique representative CRDs in IAPD & 492,841 \\
Unique RIA CRDs in IAPD & 30,579 \\
Unique CRDs in SEC Form ADV & 6,235 \\
Total IA-year Observations in IAPD & $4,623,292$ \\
Observations(2009-2014) & $1,791,522$ \\
Observations (Annual Sample) & $1,290,043$ \\
Observations (3-year window) & 382,665 \\
RIAs transitioned & 2,089 \\
Individuals transitioned & 8,698 \\
Individual-Year transitioned & 22,153 \\
\hline
\end{tabular}


Figure 8: Filing a Complaint

This figure illustrates how clients file a complaint with the New Jersey Securities Regulator.

\section{CONSUNMERESTAFFAIRS}
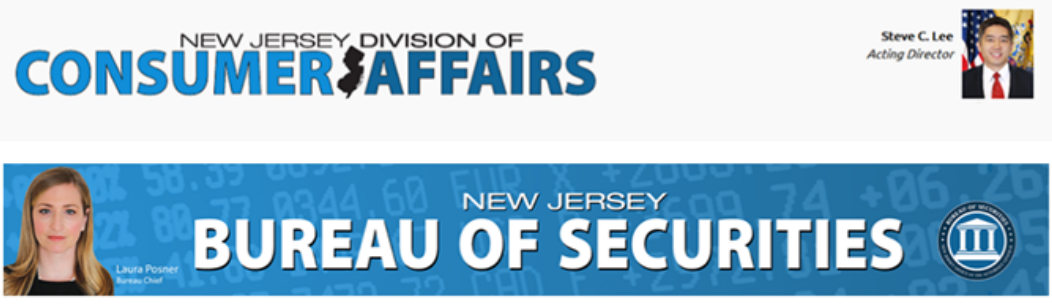

File a Complaint

The Bureau of Securities investigates complaints against individuals and firms selling securities or offering investment advice as well as companies issuing securities investments. The Bureau is empowered to bring administrative actions or civil law suits to enforce the registration and anti-fraud provisions of the New Jersey Uniform Securities Act. The Bureau may refer certain matters for criminal prosecution.

Please be advised that the Bureau does not have the specific authority to order restitution or the repayment of any monies which you may believe are due you.

Investor Information

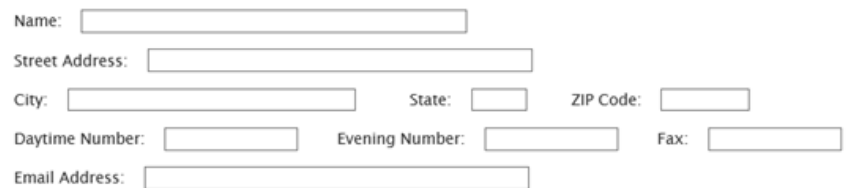

Firm Information

Firm Name:

Street Address:

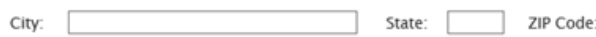

Telephone Number (1): $\quad$ Telephone Number (2):

Email Address:

Complaint Information

1. Type of firm (If known): Choose One $\quad y$

If other, please specify,

2. Name and title of firm's agents or employees with whom you dealt:

Name:

Title 


\section{B.1 Example of Complaints}

Example 1: Excessive Risk Taking

\begin{tabular}{|c|c|}
\hline Reporting Source: & Individual \\
\hline Investment Adviser: & Robert J Escamillo (CRD \# 1159079) \\
\hline $\begin{array}{l}\text { Employing firm when } \\
\text { activities occurred: }\end{array}$ & Webush Securities (CRD \# 877) \\
\hline Allegations: & $\begin{array}{l}\text { Claimant alleges unsuitable trading, heavy use of margin, } \\
\text { and speculation resulting in alleged losses. Complaint } \\
\text { also includes claims for fraud, negligent } \\
\text { misrepresentation, breach of fiduciary duty, and breach of } \\
\text { covenants of good faith and fair dealing. }\end{array}$ \\
\hline Product Type: & Equity Listed (Common \& Preferred Stock) \\
\hline Alleged Damages: & $\$ 100,000$ \\
\hline $\begin{array}{l}\text { Alleged Damages } \\
\text { Explanation: }\end{array}$ & $\begin{array}{l}\text { Claimant requests award of compensatory/economic } \\
\text { damages of } \$ 100,000 \text { or amount established at hearing } \\
\text { and reimbursement of all filing and hearing fees as well } \\
\text { as costs relating to expert witness, transcripts, and } \\
\text { analysis. }\end{array}$ \\
\hline $\begin{array}{l}\text { Date Complaint } \\
\text { Received: }\end{array}$ & November 13,2012 \\
\hline Arbitration Forum: & FINRA \\
\hline Status: & Settled \\
\hline Settlement Date: & March 7, 2014 \\
\hline $\begin{array}{l}\text { Monetary Compensation } \\
\text { Amount: }\end{array}$ & $\$ 45,000$ (individual adviser contributed $\$ 22,500$ ) \\
\hline
\end{tabular}


Example 2: Under-diversification

\begin{tabular}{|c|c|}
\hline Reporting Source: & Individual \\
\hline Investment Adviser: & Athanasios Tomaras (CRD \# 2722538) \\
\hline $\begin{array}{l}\text { Employing firm when } \\
\text { activities occurred: }\end{array}$ & Fulcrum Securities, LLC (CRD \# 131777) \\
\hline Allegations: & $\begin{array}{l}\text { Client claims that beginning late } 2013 \text { his account was } \\
\text { overly concentrated in the energy sector and that Tomaras } \\
\text { failed to execute stop loss orders as instructed by the } \\
\text { client. Client claims } \$ 63,874.13 \text { in losses as a result of } \\
\text { failure to execute stop loss orders in CLNE and PWE. } \\
\text { Client also alleges unsuitable trades. }\end{array}$ \\
\hline Product Type: & $\begin{array}{l}\text { Equity-OTC } \\
\text { Equity Listed (Common \& Preferred Stock) }\end{array}$ \\
\hline Alleged Damages: & $\$ 63,874.13$ \\
\hline $\begin{array}{l}\text { Date Complaint } \\
\text { Received: }\end{array}$ & April 27, 2015 \\
\hline Arbitration Forum: & FINRA \\
\hline Status: & Settled \\
\hline Settlement Date: & April 6, 2016 \\
\hline $\begin{array}{l}\text { Monetary Compensation } \\
\text { Amount: }\end{array}$ & $\$ 25,000.00$ \\
\hline
\end{tabular}


Example 3: Fraudulent Sale

\begin{tabular}{|c|c|}
\hline Reporting Source: & Individual \\
\hline Investment Adviser: & Erryn Michael Barkett (CRD \# 4102279) \\
\hline $\begin{array}{l}\text { Employing firm when } \\
\text { activities occurred: }\end{array}$ & Next Financial Group, Inc. (CRD \# 46214) \\
\hline Allegations: & $\begin{array}{l}\text { Customer alleges that registered representative sold her } \\
\text { away from the firm a structured product that was proved } \\
\text { to be fraudulent. }\end{array}$ \\
\hline Product Type: & Structured Military Pension Product \\
\hline Alleged Damages: & $\$ 209,727.24$ \\
\hline $\begin{array}{l}\text { Date Complaint } \\
\text { Received: }\end{array}$ & February 13, 2014 \\
\hline Arbitration Forum: & FINRA \\
\hline Status: & Settled \\
\hline Settlement Date: & June 16,2014 \\
\hline $\begin{array}{l}\text { Monetary Compensation } \\
\text { Amount: }\end{array}$ & $\$ 170,000.00$ ( $\$ 56,666.67$ contributed by Mr. Barkett) \\
\hline
\end{tabular}


Example 4: Unauthorized Trading

\begin{tabular}{|l|l|}
\hline Reporting Source: & Individual \\
\hline \hline Investment Adviser: & Brett N Canarelli (CRD \# 3243879) \\
\hline \hline $\begin{array}{l}\text { Employing firm when } \\
\text { activities occurred: }\end{array}$ & Fifth Third Securities, Inc. (CRD \# 628) \\
\hline \hline Allegations: & $\begin{array}{l}\text { Customer's attorney alleges that registered representative } \\
\text { made an unauthorized purchase of a unit investment trust } \\
\text { in January 2013. }\end{array}$ \\
\hline \hline Product Type: & Unit Investment Trust \\
\hline \hline Alleged Damages: & $\$ 74,244.10$ \\
\hline $\begin{array}{l}\text { Date Complaint } \\
\text { Received: }\end{array}$ & July 9, 2013 \\
\hline \hline Arbitration Forum: & FINRA \\
\hline \hline Status: & Settled \\
\hline \hline Settlement Date: & September 23, 2015 \\
\hline \hline $\begin{array}{l}\text { Monetary Compensation } \\
\text { Amount: }\end{array}$ & \begin{tabular}{l} 
\$50,000.00 \\
\hline
\end{tabular}
\end{tabular}


Example 5: Misappropriation of funds

\begin{tabular}{|l|l|}
\hline Reporting Source: & Firm \\
\hline \hline Investment Adviser: & Bruce Martin Harada (CRD \# 2324524) \\
\hline \hline $\begin{array}{l}\text { Employing firm when } \\
\text { activities occurred: }\end{array}$ & $\begin{array}{l}\text { Financial Network Investment Corporation (CRD \# } \\
\text { 13572) }\end{array}$ \\
\hline \hline Allegations: & $\begin{array}{l}\text { Customer seeking return of investment monies she } \\
\text { alleges the representative fraudulently procured from her } \\
\text { in October 2011 and are now unaccounted for. Also, } \\
\text { requesting recovery of tax consequences incurred in } \\
\text { funding the fictitious investment. }\end{array}$ \\
\hline \hline Product Type: & Fictitious Tax Free Investment \\
\hline \hline Alleged Damages: & $\$ 25,000$ \\
\hline \hline Date Complaint & August 21, 2012 \\
Received: & \\
\hline \hline Arbitration Forum: & FINRA \\
\hline \hline Status: & Settled \\
\hline \hline Settlement Date: & September 18, 2012 \\
\hline \hline $\begin{array}{l}\text { Monetary Compensation } \\
\text { Amount: }\end{array}$ & $\$ 26,886.00$ \\
\hline
\end{tabular}




\section{B.2 State Securities Regulators}

\section{Table 13: State Securities Regulators}

The table below shows the names of state securities regulator divisions and departments. Divisions are the smallest organizational entities that oversee securities regulation. The value is blank when a departmental hierarchy is not provided.

\begin{tabular}{|c|c|c|}
\hline State & Division Name & Department Name \\
\hline Alabama & Alabama Securities Commission & \\
\hline \multirow[t]{2}{*}{ Alaska } & \multirow[t]{2}{*}{ Banking and Securities Division } & Department of Commerce, Community, \\
\hline & & and Economic Development \\
\hline Arizona & Securities Division & Arizona Corporation Commission \\
\hline Arkansas & \multicolumn{2}{|l|}{ Arkansas Securities Department } \\
\hline California & Securities Regulation Division & Department of Business Oversight \\
\hline Colorado & Division of Securities & Department of Regulatory Agencies \\
\hline Connecticut & Securities and Business Investment Division & Department of Banking \\
\hline Delaware & Investor Protection Unit & Attorney General \\
\hline Florida & Division of Securities & Office of Financial Regulation \\
\hline Georgia & Division of Securities & Secretary of State Office \\
\hline Hawaii & Division of Securities & Department of Commerce and Consumer Affairs \\
\hline Idaho & Securities Section & Department of Finance \\
\hline Illinois & Securities Department & Secretary of State \\
\hline Indiana & Securities Division & Secretary of State \\
\hline Iowa & Securities Bureau & Insurance Division \\
\hline Kansas & Office of the Securities Commissioner & \\
\hline Kentucky & Securities Division & Department of Financial Institutions \\
\hline Louisiana & Securities Division & Office of Financial Institutions \\
\hline \multirow[t]{2}{*}{ Maine } & \multirow[t]{2}{*}{ Office of Securities } & Department of Professional and \\
\hline & & Financial Regulation \\
\hline Maryland & Securities Division & Attorney General \\
\hline Massachusetts & Securities Division & Secretary of Commonwealth \\
\hline Michigan & Corporations, Securities, and Commercial Licensing Bureau & Department of Licensing and Regulatory Affairs \\
\hline Minnesota & Securities, Franchises, and Subdivided Land & Department of Commerce \\
\hline Mississippi & Securities Division & Secretary of State \\
\hline Missouri & Securities Division & Secretary of State \\
\hline Montana & Commissioner of Securities and Insurance & Office of the Montana State Auditor \\
\hline Nebraska & Department of Banking and Finance & \\
\hline
\end{tabular}


Table 14: State Securities Regulators (continued)

\begin{tabular}{|c|c|c|}
\hline State & Division Name & Department Name \\
\hline Nevada & Nevada Securities Center & Secretary of State \\
\hline New Hampshire & Bureau of Securities Regulation & Secretary of State \\
\hline New Jersey & Bureau of Securities & Division of Consumer Affairs \\
\hline New Mexico & Securities Division & Regulation and Licensing Department \\
\hline New York & Investor Protection Bureau & Attorney General \\
\hline North Carolina & The Securities Division & Secretary of State \\
\hline North Dakota & Securities Department & \\
\hline Ohio & Division of Securities & Department of Commerce \\
\hline Oklahoma & Department of Securities & \\
\hline Oregon & Division of Financial Regulation & \\
\hline Pennsylvania & Department of Banking and Securities & \\
\hline Rhode Island & Department of Business Regulations & \\
\hline South Carolina & Securities Division & Attorney General \\
\hline South Dakota & Division of Securities & Division of Licensing and Regulation \\
\hline Tennessee & Department of Commerce \& Insurance & Department of Commerce \& Insurance \\
\hline Texas & State Securities Board & \\
\hline Utah & Division of Securities & \\
\hline Vermont & Securities Division & Department of Financial Regulation \\
\hline Virginia & Division of Securities and Retail Franchising & State Corporation Commission \\
\hline Washington & Division of Securities & Department of Financial Institutions \\
\hline West Virginia & Securities Commission & State Auditor's Office \\
\hline Wisconsin & Division of Securities & Department of Financial Institutions \\
\hline Wyoming & Investing Center & Secretary of State \\
\hline
\end{tabular}

\section{B.3 Redacting Client Complaints}

One potential concern regarding our results is that redactions increased for RIAs that were transitioned relative to those that were not transitioned. First, state regulators may be more susceptible to regulatory capture, seeking to preserve the presence of investment advisers who may otherwise leave the state. Second, the inability of adviser representatives to redact their complaints drives our results, being in 
Figure 9: State Regulator Budgets

The figure below shows the normalized proposed state securities regulator budgets so that the 2009 value is one. Most states report budgets biannually. The bold line is the average across all states. The figure makes clear that most states did not increase the budgets of the securities regulator, despite receiving extra fee revenues from transitioning advisers. During timing of the transition, states were fiscally constrained.

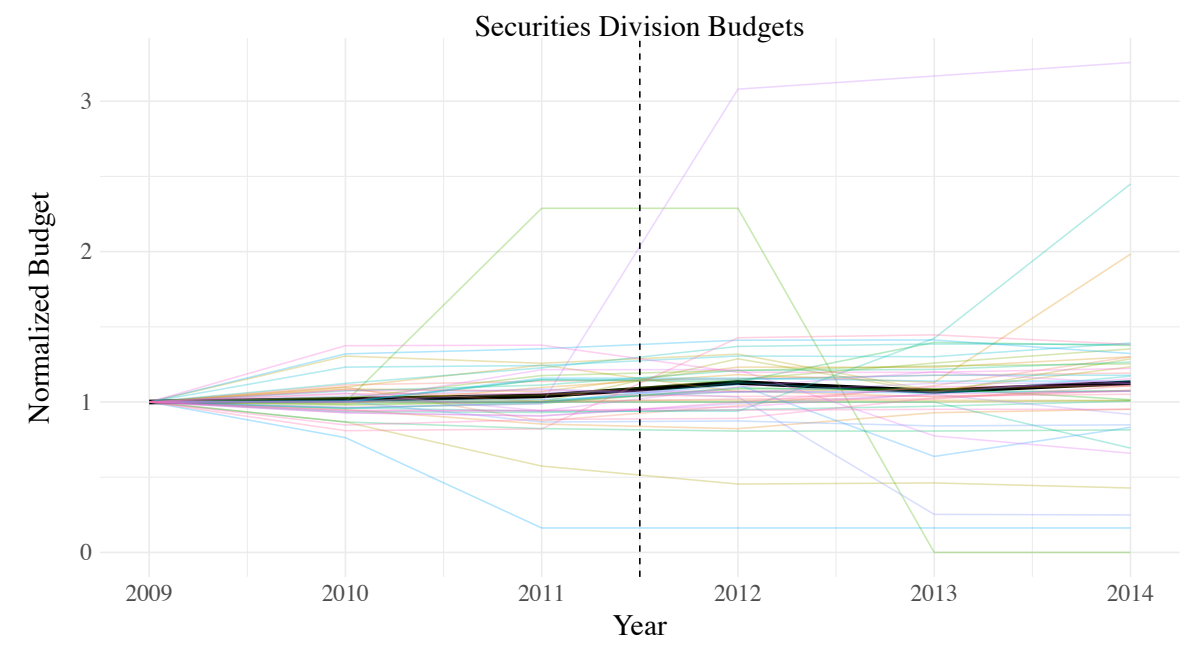


a state with more regulatory staff means more resources to process the complaints. Moreover, being farther from the corresponding state regulator would also mean redacting a complaint is more costly. We argue these alternatives are not likely in light of the legal environment through which redactions are processed.

Records are stored at FINRA through the CRD system. Complaints that have alleged damages over $\$ 5,000$ or resulted in some legal action are both reported in the system. Upon receiving a complaint, both the investment adviser RIAs and investment-adviser representative have to file a complaint disclosure to the CRD system. In August 2010, FINRA began disclosing all historic complaints, regardless of age. In the past, unproven allegations were not disclosed after two years. Specifically, investment-adviser representatives may want to remove over which advisers have little control:

1. Denied client complaints. Although denied client complaints may seem insignificant, accusations typically are accompanied by harsh words that remain on the CRD for at least two years (since 2009, accusations stay for 10 years). Even if an adviser's record shows patterns of denied rather than arbitrated or settled complaints, RIAs may be hesitant to affiliate with that adviser. Moreover, whether or not complaints are settled in the first place is mainly up to the RIA, not the representative.

2. Termination explanations. Broker-dealers may terminate advisers for any reason. Discrepancies can exist between the self-reported termination explanation and the RIA-reported explanation.

Investment advisers occasionally request expungement of client complaints. Because the records are stored in the CRD, FINRA handles all expungement requests. Nonetheless, other regulators are involved in the process. FINRA may agree to remove disclosures if brokers obtain a recommendation that is false, erroneous, or that the broker wasn't involved in the alleged misdeed. To obtain this recommendation, representatives must acquire a court confirmation after submitting an expungement request. Upon submission, the corresponding investment adviser regulator (SEC or state regulator) is informed, giving a chance to oppose the expungement. State regulators received a total of 519 requests in 2010, up from 110 in 2009. In total, the 
process to expunge a complaint typically takes at least one year. Although FINRA claims to have tracked the number of expungements granted, they do not publicly disclose it.

Although the expungement process is fairly difficult, FINRA arbitrations could be settled subject to an agreement that claimants would not oppose the investmentadviser representative's subsequent efforts to seek expungement from a court of competent jurisdiction. Subsequently, representatives would initiate unopposed petitions for expungement in state courts that were often rubber-stamped. The judge's order would then be submitted to FINRA, and the arbitration disclosure would be expunged. In response to this practice, FINRA adopted Rule 2130 in 2004. One of the most significant changes was the need to name FINRA as an additional party challenging expungement. This meant FINRA also receives all appropriate documents with expungement, unambiguously increasing the cost of expungement requests. Moreover, although expungement requests from arbitrated cases are mostly granted, less than $8 \%$ of disclosures are expunged. Of the 7,621 arbitration cases from 2012 to 2014, only 563 records were expunged, according to the arbitration bar association.

Some of the surge in requests is also the result of new disclosure demands by FINRA. Until 2009, only brokers who were named as party to a case had to disclose a client complaint. Because most investors sue only the brokerage firm, large brokerage firms could shield individual brokers from direct accusations. However, firms might not have this incentive. Larger firms may also be more likely to place blame on an individual whom they could terminate, in order to shift blame to the individual. After 2009, FINRA modified this disclosure practice, requiring all brokers to report complaints regardless of whether or not they were named directly as a respondent.

The institutional setting suggests deletions of client complaints is not relevant for the timing of the Dodd-Frank Act. Our phone calls with three regulators: California, Maryland, the SEC also suggest expungement is not an issue. Moreover, the censoring bias from any deleted complaints should not be correlated with treatment either. Finally, our specifications with state-year fixed effects and firmed fixed effects absorb a lot of the drivers of expungement. 


\section{B.4 Complaints Topics and Related Products}

Table 15: Summary of Complaint Topics and Related Types

\begin{tabular}{|c|c|c|c|c|c|}
\hline \multicolumn{3}{|c|}{ Product } & \multicolumn{3}{|c|}{ Type } \\
\hline & Number & $\%$ of Total & & Number & $\%$ of Total \\
\hline Annuity & 7,122 & 28.32 & Suitability & 9,955 & 39.58 \\
\hline Variable Annuity & 6,498 & 25.84 & Misrepresentation & 8,620 & 34.27 \\
\hline Mutual Fund & 5,371 & 21.36 & Fiduciary & 1,943 & 7.73 \\
\hline Equity & 5,040 & 20.04 & Unauthorized Trading & 1,827 & 7.26 \\
\hline Insurance & 2,108 & 8.38 & Fraud & 1,484 & 5.90 \\
\hline Debt & 2,051 & 8.16 & Fees & 1,306 & 5.19 \\
\hline Real Estate & 1,941 & 7.72 & Portfolio Allocation & 669 & 2.66 \\
\hline OTC & 1,105 & 4.39 & Churning & 567 & 2.25 \\
\hline Options & 591 & 2.35 & & & \\
\hline Fixed Annuity & 578 & 2.30 & & & \\
\hline Private Placements & 409 & 1.63 & & & \\
\hline
\end{tabular}

